\title{
Investment in Beauty, Exercise, and Self-esteem: Are They Related to Self-perception as a Romantic Partner?
}

\author{
${\text { Anthonieta Looman } \text { Mafra }^{1} \text { • Felipe Nalon Castro }}^{2}$ - Fívia de Araújo Lopes ${ }^{1}$
}

Published online: 21 October 2015

(C) Springer International Publishing 2015

\begin{abstract}
Men and women prefer certain characteristics that are interpreted as clues to the reproductive quality of potential partners. Physical appearance, for example, is an important characteristic for both sexes because it can signal youth and fertility in females and capacity for protection, dominance, competitive ability, and high social status in males. Therefore, we predicted that people would put significant effort into improving their physical attractiveness in order to compete in the mating market, and this relationship would be influenced by self-perception and socioeconomic status. In order to investigate whether investment in beauty and exercise are related to self-perception as romantic partners and self-esteem, this study was conducted with 205 men and women of lower socioeconomic status from Brazil. They were asked about their self-esteem (Rosenberg self-esteem scale), socioeconomic status, investment in beauty, time exercising, and self-perception as a romantic partner. Although no significant relationship between self-perception as a romantic partner and exercise was found, our results suggest that female investment in beauty is related to their financial condition, whereas male investment in beauty is related to greater evaluation in handsome face, beautiful body, sociability, and
\end{abstract}

Anthonieta Looman Mafra

looman.anthonieta@gmail.com

1 Department of Physiology, Graduate Program in Psychobiology, Laboratório de Evolução do Comportamento Humano, Universidade Federal do Rio Grande do Norte [UFRN], Campus Universitário, Lagoa Nova, CEP: 59078-900 Natal, RN, Brazil

2 Organizational Psychology Program, Universidade PotiguarLaureate International Universities, Roberto Freire Campus, Av. Eng. Roberto Freire, 2184, Capim Macio, CEP: 59082-902 Natal, RN, Brazil agreeableness, being correlation stronger when controlled by participants' self-esteem. The results support Leary and Baumeister's sociometer theory (2000 cited in Bale and Archer Evolutionary Psychology, 11, 68-84, 2013) and Penke and Denissen's (Journal of Research in Personality, $42,1123-1129,2008$ ) findings, in which men would associate more characteristics of their self-perception in a mate market with their self-esteem.

Keywords Sexual partners · Self-perception · Self-esteem · Socioeconomic status $\cdot$ Physical attractiveness $\cdot$ Physical activity

The sexual strategies theory provides an evolutionary framework for how human sexual behavior has been selected to improve human reproductive success during romantic partner choice (Buss and Schmitt 1993). Humans are selective about whom they have a relationship with, especially when dealing with romantic partners, and there are certain characteristics preferred by both men and women that are interpreted as clues to the reproductive quality of potential mates. Due to the high degree of time and effort invested into romantic relationships, the required level of preferred characteristics is greater compared to other kinds of relationships (Brase 2006; Cottrell et al. 2007; Fletcher et al. 2004; Sprecher and Regan 2002). Characteristics that are of fundamental importance to romantic relationships are related to physical attractiveness, personality, and financial status, for example, because they provide clues about an individual's potential fitness, suitability for personal relationship, and investment in offspring, respectively (Castro and Lopes 2011; Mafra and Lopes 2014).

Among the traits evaluated in a potential romantic partner, both sexes tend to give similar importance to characteristics related to social skills, since they provide information about the quality of the relationship (Castro and Lopes 2011). 
Fidelity is especially important to men and women in longterm relationships, a type of relationship in which the probability of offspring conception is higher. In this way, a faithful woman would assure her partner about the paternity of their offspring (Trivers 1972) and a faithful man would assure his partner about his investment of resources in their children (Gaulin and McBurney 2004).

It is argued that ancestral women were subjected to selective pressures that enabled those who chose men with greater resources, and/or capacity for resource acquisition, to have greater reproductive success compared to those who did not choose a partner with such characteristics (Brase and Guy 2004; Castro and Lopes 2011; Geary et al. 2004; Pawlowski 2000). Although physical attributes appear to have less importance in female mate choice compared to male preferences (Castro and Lopes 2011), male physical appearance can also give women clues about the genetic quality of a potential partner, as well as their capacity for protection, dominance, competitive ability, and achieving high social status (Buss and Shackelford 2008). Thus, women who choose attractive men as their romantic partners would likely be improving their own reproductive success (Buss and Shackelford 2008).

Physical attractiveness can be easily assessed by visual cues. Smooth skin, clear eyes, and lustrous hair are perceived as attractive signals of beauty, as well as symmetric and average-looking faces (Cloud and Perilloux 2014; Gangestad and Thornhill 1999, 2003; Gaulin and McBurney 2004; Jones 2014). These characteristics are clues to assess the genetic quality and history of pathogens in potential mating partners. People who display such traits are usually described as more attractive, and it is supposed that these traits can signal a good immune system to combat pathogens and sufficient energy to invest in secondary sexual characteristics and facial symmetry (Cloud and Perilloux 2014; Gangestad and Thornhill 1999, 2003; Jones 2014).

Several studies indicate that men who choose women with signs of high reproductive potential have greater reproductive success than those who choose women that do not display such signals (Buss and Schmitt 1993; Castro and Lopes 2011; Geary et al. 2004; Pawlowski 2000). This reproductive potential can be signaled by physical characteristics, such as waist-to-hip ratio and reproductive age (Castro et al. 2012; Hattori et al. 2013; Karremans et al. 2010).

Thus, mate value is the value of an individual within the mate market, which is based on what the potential partner look for in a mate, i.e., preferences of the opposite sex (Noë and Hammerstein 1995). Each sex tends to assign greater importance to self-perception as romantic partner (how an individual perceives him/herself as a romantic partner) according to what they perceive the opposite sex values in a potential mate (Fisher et al. 2008; Goodwin et al. 2012). In this sense, women give more importance to characteristics that are related to physical attractiveness when evaluating themselves as romantic partners, whereas men give greater importance to characteristics related to their financial status (Mafra and Lopes 2014).

Several studies have been conducted in order to investigate if individuals' perception of themselves (self-perception) as a romantic partner were, in fact, based on opposite sex preferences and if individual's self-perception as romantic partner is associated with its demand when looking for a romantic partner (Buston and Emlen 2003; Gutierres et al. 1999; Lee et al. 2008). Buston and Emlen (2003) and Lee and colleagues (2008) found that participants who evaluate themselves as higher in mate value are more demanding than those that evaluate themselves as having lower mate value.

In addition, Leary et al. (1995) proposed the sociometer hypothesis as a conclusion of five studies that evidenced that social exclusion is negatively related to self-esteem. The sociometer hypothesis developed into sociometer theory later (Leary and Baumeister 2000 cited in Bale and Archer 2013; Penke and Denissen 2008), which indicates that self-esteem monitors social environment for cues related to low relational quality. Based on this theory, other researchers investigated the relationship between self-perception and self-esteem. Goodwin et al. (2012), Mafra and Lopes (2014), and Penke and Denissen (2008) found a positive relationship between self-perception and self-esteem and, thus, also a perceived mate value, which can be translated into actual behavior, and social and mating interactions. Penke and Denissen (2008) went further and found a greater correlation between men's self-esteem and self-perception as romantic partners due to the greater desire for short-term relationships and, thus, higher sensitivity to potential partners' rejections. Since physical attractiveness is an important trait for both sexes, it is expected that both men and women would try to improve the expression of related characteristics. Furthermore, it is also expected that men and women would compete with potential rivals through their time and investment in beauty enhancement treatments and exercise. Evidencing female intrasexual competition, Tiggemann and Williamson (2000) found a difference of motivation to exercise between men and women, in which women exercise more for weight control and tone, being correlated with poor body satisfaction, and mood enhancement than men. They also found that when both sexes exercise for fitness and health, there is an increase of their self-esteem.

Additionally, Edmonds (2007) noted that in Brazil, which displaced the USA as the world's leader in cosmetic surgery, low self-esteem is one of the recurring motivations for people realizing cosmetic surgeries. According to the author, Brazilian women feel pressured to achieve the desirable standards of beauty perceived through the media to find a high-ranking romantic partner or be successful in the labor market. The pressure to achieve the standards of beauty is even greater within women of low socioeconomic status, since the 
improvement of physical attractiveness increases the chance of getting jobs (Edmonds 2007).

The current study aims to investigate the impact of individual investment in beauty on self-perception as a romantic partner in participants of low socioeconomic status. This group of participants and this line of investigation have been neglected for the most part in previous studies of mate selection, resulting in a greater necessity of studies contemplating them. Our specific objectives were to investigate whether there are differences in beauty investment between sexes. First, although investment in beauty can be a way that both men and women improve their appearance to attract potential romantic partners, we hypothesized that women would invest more time and effort in beauty than men due to the importance given by men to female physical appearance, accordingly to the sexual strategies theory (Buss and Schmitt 1993). Secondly, we investigated if there is a difference between sexes with respect to the investment of time and effort in exercises. In this way, men are generally more engaged in direct competition with one another than women are (Deaner et al. 2012), so that our hypothesis is that men should be expected to exercise more than women. Thirdly, whether exercise is related to monetary investment in beauty: as both exercise and investment in beauty can help individuals to feel better about themselves and improve their overall physical attractiveness (Avelar and Veiga 2013), we expected that those participants who invest more in beauty products and services should also engage in more exercise. Fourthly, if the amount of exercise done is related to self-perception as romantic partners: given that exercise serves as a way to increase individual attractiveness, we expected that those participants who exercise more should also have a better perception of themselves as a romantic partner that those participants who exercise less. Two hypotheses were originated for this aim, each one based on a different background. Following sexual strategies theory (Buss and Schmitt 1993), we predicted that compared to men, women should show a relationship between the amount of exercise they engage in and more traits of their self-perception as romantic partners, since physical appearance is more important to their mate value. On the other hand, leading by sociometer theory (Leary and Baumeister 2000 cited in Bale and Archer 2013; Penke and Denissen 2008), we expected that men would present more traits of their self-perception related to amount of exercise done, since their self-esteem is closely related to their self-perception as romantic partners than women's selfesteem. And fifthly, whether monetary investment in beauty is related to self-perception as romantic partners: considering that investment in beauty serves as a way to increase individual attractiveness, we expected a positive relationship between investment in beauty and self-perception as a romantic partner both for men and women. We are going to test two hypotheses here again, also based on sexual strategies theory (Buss and Schmitt 1993) and on sociometer theory (Leary and Baumeister 2000 cited in Bale and Archer 2013; Penke and Denissen 2008), respectively. As physical attractiveness is expected to be more important for self-perception in women, according to Buss and Schmitt (1993), we hypothesized that women would show a more positive relationship between their self-perception as romantic partners and their degree of investment in beauty enhancement. And, according to Leary and Bausmeister (2000, cited in Bale and Archer 2013; Penke and Denissen 2008), we expected that men would present more traits of their self-perception related to amount of exercise done, since their self-esteem is more closely related to their self-perception as romantic partners than women's selfesteem.

\section{Methods}

\section{Participants}

Ninety-five female $(M=22.42$ years; $\mathrm{SD}=5.33)$ and 110 male $(M=20.64$ years; $\mathrm{SD}=4.25)$ elementary and high school (EHS) students from nine public schools in the city of Natal, Brazil, took part in the current study (approved by the Ethics in Research Committee-no. 31266514.9.0000.5537). Most of the EHS students from public schools in Natal are of low socioeconomic status (see below the exact status), and a proportion of them have to drop out of school or are not able to focus on their education at certain point of their lives because they must enter the labor market in order to support themselves or, in some cases, to contribute to the survival of their whole family. Therefore, a large part of the students that eventually return to school are relatively older than those who were able to be more dedicated to their studies. Taking this reality into account, we limited our sample to students ranging from 18 to 35 years of age.

\section{Procedure and Instruments}

Standardized questionnaires were distributed in classrooms during a predetermined time that the teachers granted to us as part of their regular class and allowed students who wanted to take part in the research to volunteer their time. The participants signed a consent form confirming their agreement to participate in the study and were clearly informed of the anonymous and voluntary nature of the research. After signing the consent form and returning it to the researcher, each participant was asked to fill out a questionnaire.

The average of time spent completing the questionnaire was $20 \mathrm{~min}$ and each questionnaire included five categories: (1) Rosenberg self-esteem scale, (2) Self-perception as a romantic partner, (3) Exercise information, (4) Investment in beauty information, and (5) Demographic and personal questions.

1. The Rosenberg self-esteem scale is a 4-point Likert scale that contains ten statements designed to assess how 
people feel about themselves (ranging from "Strongly agree" to "Strongly disagree") (Rosenberg 1989). This scale was translated and adapted to Portuguese and validated for the Brazilian population with a Cronbach alpha value of 0.9 (Hutz and Zanon 2011).

2. Self-perception as a romantic partner (based on Castro and Lopes 2011): each participant evaluated him/herself according to nine traits (pretty/handsome face, beautiful body, and healthy — related to physical appearance; determined and hard working, good financial condition, and intelligent—related to financial status; and agreeableness, sociability, and faithfulness - related to personality) on a 10-point Likert scale for each trait (such that the more points the participants attributed to themselves, the more of that characteristic they thought they possessed as a romantic partner).

3. Exercise information: we asked the participants how many times they typically exercise in a week and the duration of each session in minutes. With these two bits of information, we were able to calculate the time spent engaged in exercise per week for each participant.

4. Investment in beauty information: here, the participants were only asked about the average amount of money they spent per week on beauty enhancement in general (cosmetic products and/or surgery, massages, gym membership, lymphatic drainage, etc.). The values were given in Reais (Brazil currency).

5. Demographic and personal questions: the participants filled in their sex, age, age when got married (or that want to get married, if the participant had not got married yet), relationship status, number of children, and socioeconomic status. The participants answered questions regarding their socioeconomic status conforming to the classification system of the Brazilian Association of Research Companies (ABEPAssociação Brasileira de Empresas de Pesquisa 2012). Applying this system of classification (ABEP 2012) to our sample, most men were classified at the $\mathrm{C} 1$ level (average family income of $\mathrm{R} \$ 1541.00 /$ month or approximately US\$670.00/month) and most women were classified at the $\mathrm{C} 2$ level (average family income of $\mathrm{R} \$ 1024.00 /$ month or approximately US $\$ 445.22 /$ month).

\section{Statistical Analyses}

Given that self-esteem is related to self-perception (Brase and Guy 2004; Penke and Denissen 2008) and investment in beauty (Avelar and Veiga 2013; Edmonds 2007), we included it as a covariate in order to control its effects on investment in beauty and on self-perception as romantic partner. To analyze if there is a difference in investment in beauty between the sexes (hypothesis 1) and if there is any difference in the amount of exercise per week between sexes (hypothesis 2), we conducted ANCOVA and ANOVA to test each hypothesis. That way, we could also compare the results of controlling (ANCOVA) or not controlling (ANOVA) for self-esteem. For the analysis of these hypotheses, sex was treated as the independent variable and investment in beauty and exercise as dependent variables. In order to analyze if there is any relationship between exercise and investment in beauty (hypothesis 3), exercise and self-perception (hypothesis 4), and investment in beauty and self-perception (hypothesis 5), we performed one partial and one Pearson correlation for each hypothesis. Therefore, we could also compare the results of controlling (partial correlation) or not controlling (Pearson correlation) for self-esteem. Self-perception, investment in beauty, and the degree of engagement in exercise were the variables considered in these hypotheses. The data were analyzed using the statistics program (SPSS Statistics 20), with the alpha level for interpreting results set at .05 .

\section{Results}

\section{Exercise and Investment in Beauty: Difference of Means and Correlation Between These Variables}

The results of ANCOVA and the ANOVA between sexes and exercise showed that men exercise more than women $(F(1$, $172)=21.620, p<.001$, partial $\eta^{2}=.113$, power $=.996 ; F(1$, 176) $=22.272, p<.001$, partial $\eta^{2}=.112$, power $=.997 ; M_{\text {men }}=$ $354.55 \mathrm{~min} /$ week, $M_{\text {women }}=170.73 \mathrm{~min} /$ week) and although women invested in beauty more than men, the difference of investment between the sexes was not significant $(F(1,154)=$ $2.827, p=.095$, partial $\eta^{2}=.018$, power $=.386 ; F(1,155)=$ $3.060, p=.082$, partial $\eta^{2}=.019$, power $=.412 ; M_{\text {men }}=$ $\mathrm{R} \$ 119.15 /$ month, $M_{\text {women }}=\mathrm{R} \$ 166.15 /$ month). In order to verify if there was a relationship between exercise and investment in beauty, Pearson and partial correlations were calculated and the output indicated that only women showed a positive relationship between both variables (Pearson: $r(70)_{\text {women }}=.368$, $p_{\text {women }}=.002 ; r(74)_{\text {men }}=.133, p_{\text {men }}=.254 ;$ partial: $r$ $\left.(67)_{\text {women }}=.375, p_{\text {women }}=.002 ; r(71)_{\text {men }}=.135, p_{\text {men }}=.256\right)$.

\section{Exercise $\times$ Self-perception: Pearson and Partial Correlations}

No significant results were found for women or men when we conducted Pearson and partial correlations between exercise and self-perception as a romantic partner (Table 1).

\section{Investment in Beauty $\times$ Self-perception: Pearson and Partial Correlations}

The Pearson correlations showed that the sample of men who invest more in beauty also considered themselves to be more 
Table 1 Outputs of Pearson and partial correlation between exercise and self-perception as a romantic partner for women and men

\begin{tabular}{|c|c|c|c|c|c|c|c|c|}
\hline & \multicolumn{4}{|c|}{ Women } & \multicolumn{4}{|l|}{ Men } \\
\hline & \multicolumn{2}{|c|}{ Pearson $(n=77)$} & \multicolumn{2}{|c|}{ Partial $(n=74)$} & \multicolumn{2}{|c|}{ Pearson $(n=97)$} & \multicolumn{2}{|c|}{ Partial $(n=90)$} \\
\hline & $r$ & $p$ & $r$ & $p$ & $r$ & $p$ & $r$ & $p$ \\
\hline Beautiful face & -.020 & .864 & -.016 & .891 & .063 & .538 & .093 & .382 \\
\hline Beautiful body & -.017 & .881 & -.028 & .809 & .126 & .220 & .181 & .086 \\
\hline Healthy & .070 & .546 & .060 & .611 & .160 & .117 & .162 & .125 \\
\hline Financial status & .124 & .284 & .127 & .278 & .063 & .541 & .047 & .655 \\
\hline Sociable & .029 & .804 & .039 & .739 & .000 & .997 & .052 & .626 \\
\hline Deter./hardwork & .144 & .212 & .152 & .192 & -.116 & .257 & -.119 & .262 \\
\hline Intelligent & -.036 & .755 & -.029 & .802 & -.037 & .721 & -.024 & .819 \\
\hline Agreeable & .111 & .336 & .122 & .292 & .006 & .953 & .044 & .677 \\
\hline Faithful & .115 & .320 & .121 & .301 & -.105 & .305 & -.067 & .528 \\
\hline
\end{tabular}

Deter./hardwork determined/hardworking handsome $(r(81)=.257 ; p=.020)$ and a positive relationship between investment in beauty and financial status in women $(r(72)=.310 ; p=.008)$. A partial correlation between investment in beauty and self-perception as a romantic partner showed a positive relationship between the characteristics handsome face $(r(78)=.299 ; p=.007)$, beautiful body $(r(78)=.246 ; p=.028)$, sociability $(r(78)=.266 ; p=.017)$, and agreeableness $(r(78)=.237 ; p=.035)$ and investment in beauty, while the characteristic related to investment in beauty in women was good financial status $(r(69)=.335 ; p=.004)$ (Table 2).

\section{Discussion}

Our results indicate that men exercise more than women, but that their engagement in exercise is not related to investment in beauty as in women. Also, no relationship between exercise and self-perception as a romantic partner was found in either men or women, failing to support predictions of both sociometer and sexual strategies theories. However, men showed a positive correlation between investment in beauty and handsome face, beautiful body, sociability, and agreeableness, while women who were in better financial condition invested more in their beauty, providing support to sociometer theory over sexual strategies theory.

In environments where physical appearance plays an important role, women's perception of physical attractiveness is related to self-esteem (Mafra and Lopes 2014; Penke and Denissen 2008). Avelar and Veiga (2013) noted that excessive concern about physical appearance is positively associated with the necessity for physical and material resources and that when media emphasizes the distance between the physical appearance of ordinary women and some ideal standards of female beauty, it can have the affect of lowering self-esteem in most women, increase concern about their appearance, and lead to behaviors or activities that might help to boost selfesteem. These findings serve as a basis to understand why, in our study, a positive relationship was only observed between investment in beauty and the trait good financial condition in women, which indicates that among women of low socioeconomic status, those having a slightly better financial condition, invested more money in beauty. Probably because these women have more resources that can be dedicated to improving their appearance, in contrast to other women who mainly direct their resources to sustenance.

Highlighting the difference in socioeconomic status in the Brazilian population, Mafra and Lopes (2014) conducted a study addressing self-perception as a romantic partner in participants of high and low socioeconomic status. This research found that although self-rated physical attractiveness was related to self-esteem in women of high socioeconomic status, in women of low socioeconomic status, self-esteem was related to both physical attractiveness and including traits related to their social status. Usually, characteristics related to financial status are typically associated with self-esteem in men (Goodwin et al. 2012; Mafra and Lopes 2014), but this work showed that, in fact, different characteristics influence selfesteem in women of low socioeconomic status compared to women of high socioeconomic status, lending additional support to the importance of further research comparing population of lower and higher socioeconomic status.

Due to the greater social and media pressures on female than on male attractiveness, men have less opportunity for social ascension by improving their physical appearance than women do, leading to men who invest more in beauty perceiving themselves as fitter, more handsome, more agreeable, and more sociable than men who invest less in beauty. In men, reproductive success generally depends more on social status than it does on physical attractiveness (Kenrick et al. 1990; 
Table 2 Outputs for Pearson and partial correlations between investment in beauty and selfperception as a romantic partner for women and men

\begin{tabular}{|c|c|c|c|c|c|c|c|c|}
\hline & \multicolumn{4}{|c|}{ Women } & \multicolumn{4}{|l|}{ Men } \\
\hline & \multicolumn{2}{|c|}{ Pearson $(n=73)$} & \multicolumn{2}{|c|}{ Partial $(n=70)$} & \multicolumn{2}{|c|}{ Pearson $(n=82)$} & \multicolumn{2}{|c|}{ Partial $(n=79)$} \\
\hline & $r$ & $p$ & $r$ & $p$ & $r$ & $p$ & $r$ & $p$ \\
\hline Beautiful face & -.125 & .290 & -.113 & .347 & .257 & .020 & .299 & .007 \\
\hline Beautiful body & -.061 & .610 & -.035 & .772 & .203 & .068 & .246 & .028 \\
\hline Healthy & .091 & .445 & .126 & .296 & .123 & .270 & .155 & .170 \\
\hline Financial status & .310 & .008 & .335 & .004 & .175 & .116 & .202 & .072 \\
\hline Sociable & .039 & .740 & .060 & .621 & .210 & .059 & .266 & .017 \\
\hline Deter./hardwork & .140 & .236 & .168 & .161 & -.182 & .101 & -.191 & .090 \\
\hline Intelligent & .059 & .617 & .097 & .419 & .083 & .456 & .116 & .304 \\
\hline Agreeable & .042 & .723 & .073 & .543 & .174 & .117 & .237 & .035 \\
\hline Faithful & .149 & .210 & -.052 & .668 & -.032 & .774 & -.034 & .766 \\
\hline
\end{tabular}

Significant values $(p<.05)$ in italics

Deter./hardwork determined/hardworking
Kruger et al. 2010; Pawlowski 2000; Trivers 1972). It does not indicate that men invest more heavily in beauty than women (as showed in our results that there is no difference of investment in beauty between sexes), but that the investment that men do aggregate greater benefits for their self-perception as a romantic partner that the investment that women do.

This result supported our hypothesis based on Penke and Denissen findings explained by sociometer theory (Leary and Baumeister 2000 cited in Penke and Denissen 2008), in which men would have more characteristics of their self-perception as a romantic partner related to investment in beauty. It is also in direct opposition to our hypothesis based on sexual strategies theory (Buss and Schmitt 1993) because men of low socioeconomic status in our study who invested more in beauty rated themselves as more physically attractive (handsome face and beautiful body), but this relationship was not found for women. This result was even stronger when we controlled for men's self-esteem, which indicates that self-esteem attenuates the relationship between investment in beauty and selfrated physical appearance. The absence of this relationship for women may be due to the greater importance that self-esteem has to men's self-perception, as compared to women's selfperception, in the mate market. In particular, men do not experience the same level of pressure as women with respect to their physical appearance, which may lead women who have more resources to invest more in beauty enhancement. Thus, women feel more acutely the effects of needing to invest in beauty in order to simply maintain their status in the mating market, whereas men generally feel less pressured to invest in beauty enhancements. Men who nevertheless invest more in beauty may therefore be more likely to evaluate themselves better in several characteristics. In addition, men of low socioeconomic status who invest in beauty probably feel they have an advantage over men who do not invest in it, by being more physically attractive as a way to compensate their scarcity of resources.

Environments with higher uncertainty may lead to higher and earlier reproductive rates in a population, intensifying male competition for status and resources (Kruger 2014) and increasing the expression of violent behaviors (Puts et al. 2014). Considering that testosterone is associated with higher levels of violence and intensity of male competition and that men have higher levels of testosterone than women, these facts prompt an expectation of social and athletic challenges (Kruger 2014). Thus, men tend to be more engaged in exercise than women (Deaner et al. 2012), which provides an additional corroboration to the prediction that men should invest more in exercise than women, although women should be motivated by achieving the "perfect look."

Although both men and women exercise to improve themselves, there are slightly different signals that exercise sends. Women generally exercise, besides for health reasons, to improve their appearance of youth and fertility. Men generally exercise to improve their appearance of strength and dominance. These differential motivations would imply sexdifferentiate correlations between exercise and its possible effects. These different motivations and outcomes, along with the particular measures used in the present study, could explain the positive relationship between exercise and investment in beauty found in women, but not in men.

As exercise requires a lot of time investment and the results generally take a long time to be noticed, women might intensify their appearance improvements by other investments into beauty with faster and more noticeable results. This might explain investment in beauty and exercise correlated in women but did not relate to self-perceived attractiveness. Hudders et al. (2014) found that women invest more in items that improve their physical appearance as a tactic to increase their 
ability to compete for a mate with other women. In this line, investments in beauty may be a result of intrasexual competition among females, directing women to invest greater resources in order to try to attract or retain a partner, instead of necessarily leading to an increase in self-perception as romantic partners, before the lack of enough amount resources needed to purchase items that could, in fact, improve their appearance.

The current study has some notable limitations. The data about investment in beauty were lumped together, which makes it not possible to analyze which forms of investment in beauty are most used. Another evident limitation is the use of monetary investment in beauty as an operational definition, which is incomplete because investment in beauty can be achieve in nonmonetary actions. Prichard and Tiggemann (2011), for example, found that women also intend to eat healthier, engage in dietary restrictions, and exercise more to invest in appearance, and all the activities are not monetary related. Further studies may employ wider measures, including behavioral patterns and time investment in beauty enhancement. Although a recent study pointed out that women invest greater resources in their appearance in a context of intrasexual competition (Hudders et al. 2014), we did not ask the participants about how threatened they feel by their same sex peers. Because of this, we could not investigate if investments in beauty (physical attractiveness improvement) are better described as a self-promotion strategy or as investment in improving appearance (more related to accessories, as clothes, jewelry, and pursues, used to enhance appearance but not being related to change in individuals physical).

Also, further investigations may consider the user of regression analyses to directly examine the relationship between variables. While the present study investigated the relationship between variables and it would be interesting to investigate (and contrast) the capacity of prevision of the predictors, i.e., which characteristics of self-perception as a romantic partner can explain the amount that individuals invest in beauty. However, this type of analysis may only be applied with large samples due to the sample effect be small or medium it is regarding to the evaluation of subjective components.

Thus, the results of the current study highlight the importance of additional research on this subject. There is ample opportunity for future studies that can better explain how men and women differ in their investment in beauty and further investigate what leads men and women to invest more in beauty: attempting to improve self-perception or intrasexual competition.

Acknowledgments This research was supported by Coordenação de Aperfeiçoamento de Pessoal do Nível Superior (CAPES) awarded to Anthonieta Looman Mafra and by Conselho Nacional de Desenvolvimento Científico e Tecnológico $(\mathrm{CNPq})$ awarded to Fívia de Araújo Lopes (no. 409111/2013-9).
We thank CNPq (no. 409111/2013-9) and CAPES for supporting the development of the research; we thank the participants who agreed to complete the questionnaire, mainly considering that the research was voluntary and without financial and/or material return; we also thank teachers as well as the schools' directors for making their classes available for the data collection. We also thank the valuable comments of the reviewers that improved considerably our paper.

\section{Compliance with Ethical Standards}

Conflict of Interest The authors declare that they have no competing interests.

\section{References}

Associação Brasileira de Empresas de Pesquisa (ABEP) Brazilian Association of Research Companies (2012). Dados com base no levantamento socioeconômico de 2010 [Data based on 2010 socioeconomic survey] -IBOPE. www.abep.org.

Avelar, C. F. P., \& Veiga, R. T. (2013). Como entender a vaidade feminina utilizando a autoestima e a personalidade [How to understand women's vanity using self-steem and personality], Revista de Administração de Empresas, 53(4), 338-349. Retrieved from: http://www.spell.org.br/documentos/ver/10574/como-entender-avaidade-feminina-utilizando-a-autoestima-e-a-personalidade/i/pt-br.

Bale, C., \& Archer, J. (2013). Self-perceived attractiveness, romantic desirability and self-esteem: a mating sociometer perspective. Evolutionary Psychology, 11, 68-84. PMid:23353113.

Brase, G. L. (2006). Cues of parental investment as a factor in attractiveness. Evolution and Human Behavior, 27, 145-157. doi:10.1016/j. evolhumbehav.2005.06.003.

Brase, G. L., \& Guy, E. C. (2004). The demographics of mate value and self-esteem. Personality and Individual Differences, 36, 471-484. doi:10.1016/S0191-8869(03)00117-X.

Buss, D. M., \& Schmitt, D. P. (1993). Sexual strategies theory: an evolutionary perspective on human mating. Psychological Review, 100, 204-232. doi:10.1037/0033-295X.100.2.204.

Buss, D. M., \& Shackelford, T. K. (2008). Attractive women want it all: good genes, economic investment, parenting proclivities, and emotional commitment. Evolutionary Psychology, 6, 134-146. Retrieved from: http://www.epjournal.net/wp-content/uploads/ EP06134146.pdf

Buston, P., \& Emlen, S. (2003). Cognitive processes underlying human mate choice: The relationship between self-perception and mate preference in Western society. Proceedings of the National Academy of Sciences, 100(15), 8805-8810. doi:10.1073/pnas. 1533220100

Castro, F. N., \& Lopes, F. A. (2011). Romantic preference in Brazilian undergraduate students: from the short term to the long term. Journal of Sex Research, 47, 1-7. doi:10.1080/00224499.2010. 506680.

Castro, F. N., Hattori, W. T., \& Lopes, F. A. (2012). Relationship maintenance or preference satisfaction? Male and female strategies in romantic partner choice. Journal of Social, Evolutionary, and Cultural Psychology, 6, 217-226. doi:10.1037/h0099213.

Cloud, J. M., \& Perilloux, C. (2014). Bodily attractiveness as a window to women's fertility and reproductive value. In V. A. WeekesShackelford \& T. K. Shackelford (Eds.), Evolutionary perspectives on human sexual psychology and behavior (pp. 135-152). New York: Springer.

Cottrell, C. A., Neuberg, S. L., \& Li, N. P. (2007). What do people desire in others? A sociofunctional perspective on the importance of 
different valued characteristics. Journal of Personality and Social Psychology, 92, 208-231. doi:10.1037/0022-3514.92.2.208.

Deaner, R. O., Geary, D. C., Puts, D. A., Ham, S. A., Kruger, J., Fles, E., Winegard, B., \& Grandis, T. (2012). A sex difference in the predisposition for physical competition: males play sports much more than females even in the contemporary U.S. PLoS ONE, 7(11), e49168. doi:10.1371/journal.pone.0049168.

Edmonds, A. (2007). 'The poor have the right to be beautiful': cosmetic surgery in neoliberal Brazil. Journal of the Royal Anthropological Institute (N.S.), 13, 363-381. doi:10.1111/j.1467-9655.2007.00427.x.

Fisher, M., Cox, A., Bennett, S., \& Gavric, D. (2008). Components of self-perceived mate value. Special Issue: Proceedings of the 2nd Annual Meeting of the North-Eastern Evolutionary Psychology Society. Journal of Social, Evolutionary, and Cultural Psychology, 2, 156-168. doi:10.1037/h0099347.

Fletcher, G. J., Tither, J. M., O'Loughlin, C., Friesen, M., \& Overall, N. (2004). Warm and homely or cold and beautiful? Sex differences in trading off traits in mate selection. Personality and Social Psychology Bulletin, 30, 659-672. doi:10.1177/0146167203262847.

Gangestad, S. W., \& Thornhill, R. (1999). Individual differences in developmental precision and fluctuating asymmetry: a model and its implications. Journal of Evolutionary Biology, 12, 402-416. doi:10. 1046/j.1420-9101.1999.00039.x.

Gangestad, S. W., \& Thornhill, R. (2003). Facial masculinity and fluctuating asymmetry. Evolution and Human Behavior, 24, 231-241. doi: 10.1016/S1090-5138(03)00017-5.

Gaulin, S. J., \& McBurney, D. H. (2004). Chapter 12: The psychology of human mating. In S. J. Gaulin \& D. H. McBurney (Eds.), Psychology: an evolutionary approach (pp. 257-289). New Jersey: Pearson Education.

Geary, D., Vigil, J., \& Byrd-Craven, J. (2004). Evolution of human mate choice. Journal of Sex Research, 41, 27-42. doi:10.1080/ 00224490409552211.

Goodwin, R., Marshall, T., Fülöp, M., Adonu, J., \& Spiewak, S. (2012). Mate value and self-esteem: evidence from eight cultural groups. PLoS ONE, 7, e36106. doi:10.1371/journal.pone.0036106.

Gutierres, S., Kenrick, D., \& Partch, J. (1999). Beauty, dominance, and the mating game: contrast effects in self-assessment reflect gender differences in mate selection. Personality and Social Psychology Bulletin, 25, 1126-1134. doi:10.1177/01461672992512006.

Hattori, W. T., Castro, F. N., \& Lopes, F. A. (2013). Mate choice in adolescence: idealizing romantic partners. Psico (PUCRS), 44, 226-234. Retrieved from: http://revistaseletronicas.pucrs.br/ojs/ index.php/revistapsico/article/viewFile/11466/9641

Hudders, L., De Backer, C., Fisher, M., \& Vyncke, P. (2014). The rival wears prada: luxury consumption as a female competition strategy. Evolutionary Psychology, 12(3), 570-587. PMid: 25299993.

Hutz, C. S., \& Zanon, C. (2011). Revisão da adaptação, validação e normatização da escala de autoestima de Rosenberg. Avaliação Psicológica [Review of the Adaptation, Validation, and Standardization of Rosenberg Self-Esteem Scale. Psychological Assessment], 10, 41-49. Retrieved from: de http://pepsic.bvsalud. org/scielo.php?script=sci_arttext\&pid=S167704712011000100005\&lng=pt\&tlng=pt.

Jones, B. C. (2014). Agreement and individual differences in men's preferences for women's facial characteristics. In V. A. WeekesShackelford \& T. K. Shackelford (Eds.), Evolutionary perspectives on human sexual psychology and behavior (pp. 87-102). New York: Springer.
Karremans, J., Frankenhuis, W., \& Arons, S. (2010). Blind men prefer a low waist-to-hip ratio. Evolution and Human Behavior, 31, 182186. doi:10.1016/j.evolhumbehav.2009.10.001.

Kenrick, D. T., Sadalla, E. K., Groth, G., \& Trost, M. R. (1990). Evolution, traits, and the stages of human courtship: qualifying the parental investment model. Journal of Personality, 58, 97-116. doi: 10.1111/j.1467-6494.1990.tb00909.x.

Kruger, D. J. (2014). Social and environmental conditions intensifying male competition for resources, status, and mates lead to increased male mortality. In V. A. Weekes-Shackelford \& T. K. Shackelford (Eds.), Evolutionary perspectives on human sexual psychology and behavior (pp. 153-172). New York: Springer.

Kruger, D. J., Fitzgerald, C., \& Peterson, T. (2010). Female scarcity reduces women's marital ages and increases variance in men's marital ages. Evolutionary Psychology, 8, 420-431. Retrieved from: http://www.epjournal.net/wp-content/uploads/EP08420431.pdf.

Leary, M. R., Tambor, E. S., Terdal, S. K., \& Downs, D. L. (1995). Selfesteem as an interpersonal monitor: the sociometer hypothesis. Journal of Personality and Social Psychology, 68, 518-530. doi: 10.1037/0022-3514.68.3.518.

Lee, L., Loewenstein, G., Ariely, D., Hong, J., \& Young, J. (2008). If I'm not hot, are you hot or not? - Physical attractiveness evaluations and dating preferences as a function of one's own attractiveness. Psychological Science, 19(7), 669-677. doi:10.1111/j.1467-9280. 2008.02141.x

Mafra, A. L., \& Lopes, F. L. (2014). "Am I good enough for you?" Features related to self-perception and self-esteem of Brazilians from different socioeconomic status. Psychology, 5, 653-663. doi: 10.4236/psych.2014.57077.

Noë, R., \& Hammerstein, P. (1995). Biological markets. Trends in Ecology \& Evolution, 10(8), 336-339. doi:10.1016/S01695347(00)89123-5.

Pawlowski, B. (2000). The biological meaning of preferences on the human mate market. Anthropological Review, 63, 39-72. Retrieved from: http://www.academia.edu/3298609/The biological meaning of preferences on the human mate market.

Penke, L., \& Denissen, J. (2008). Sex differences and lifestyle-dependent shifts in the attunement of self-esteem to self-perceived mate value: hints to an adaptive mechanism? Journal of Research in Personality, 42, 1123-1129. doi:10.1016/j.jrp.2008.02.003.

Prichard, I., \& Tiggemann, M. (2011). Appearance investment in Australian brides-to-be. Body Image, 8, 282-286. doi:10.1016/j. bodyim.2011.03.001.

Puts, D. A., Doll, L. M., \& Hill, A. K. (2014). Sexual selection on human voices. In V. A. Weekes-Shackelford \& T. K. Shackelford (Eds.), Evolutionary perspectives on human sexual psychology and behavior (pp. 69-86). New York: Springer.

Rosenberg, M. (1989). Society and the adolescent self-image. Middletown: Wesleyan University Press.

Sprecher, S., \& Regan, P. C. (2002). Liking some things (in some people) more than others: partner preferences in romantic relationships and friendships. Journal of Social and Personal Relationships, 19, 463481. doi:10.1177/0265407502019004048.

Tiggemann, M., \& Williamson, S. (2000). The effect of exercise on body satisfaction and self-esteem as a function of gender and age. Sex Roles, 43(1-2), 119-127. doi:10.1023/A:1007095830095.

Trivers, R. (1972). Parental investment and sexual selection. In B. Campbell (Ed.), Sexual selection and the descent of man (pp. 136179). Chicago: Aldine-Atherton. 